\title{
TCOM \\ Science communication for the Deaf in the pandemic period: absences and pursuit of information
}

\section{Alexandre G. Silva, Tiago Batista, Felipe Giraud, Andrea Giraud, Flavio Eduardo Pinto-Silva, Julia Barral, Juan Nascimento Guimarães and Vivian M. Rumjanek}

\begin{abstract}
COVID-19 pandemic hit Brazil in February 2020. Controversial information, minimization of the problem, and difficulties resulting from extreme social inequality, led to the intensification of the disease and number of deaths. During this period, the government failed to provide information to the Deaf minority that uses Brazilian Sign Language to communicate. This study analyzes information provided by a TV with accessibility, as well as a Facebook page created by Deaf and hearing interpreters, and videos posted on Instagram and YouTube for that community. The novelty of the subject required linguistic efforts so that information could be coherent in sign language.
\end{abstract}

Keywords

Community action; Risk communication; Social inclusion

DOI

https://doi.org/10.22323/2.19050205

Submitted: 26th June 2020

Accepted: 17th August 2020

Published: 30th September 2020

Context

The first evidence of a new infectious agent, capable of producing an epidemic that spread rapidly and produced a disease that led, in severe cases, to acute respiratory failure, came from Wuhan, in the province of Hubei in China, on December 2019. On January $7^{\text {th }}, 2020$, the agent was identified as a new coronavirus SARS-CoV2 [Gralinski and Menachery, 2020; Lu, Stratton and Tang, 2020]. Soon other countries like Thailand, Japan, South Korea, Iran and Italy started to present cases of this disease. On January $30^{\text {th }}, 2020$, the general director of the World Health Organization declared this SARS-CoV2 pneumonia an Emergency and International Public Health Problem and on March $11^{\text {th }}$ declared it a pandemic [Cucinotta and Vanelli, 2020]. Recognized as a pandemic, the disease produced by SARS-CoV2 was named COVID-19. As of May 31 ${ }^{\text {st }}$, the disease had already affected more than 200 countries with different degrees of intensity [Worldometer, 2020] and the total number of infected people in the world reached $6,238,549$ with an observed case fatality ratio of $11.6 \%$ deaths. 
In Brazil, the first confirmed case was in the State of S.Paulo on February $26^{\text {th }}$ and the first death on March $17^{\text {th }}$ [Croda et al., 2020; Werneck and Carvalho, 2020]. Since then, cases of COVID-19 have been reported in different parts of the country. The total number of infections by May $31^{\text {st }}$ in Brazil was 278,980 with 29,314 deaths [Worldometer, 2020]. However, one must consider that few people have been tested and it is believed that there is a large percentage of underreporting. In the countries most affected, on the same day, the number of accumulated deaths was 106,432 in the United States, 38,394 in the United Kingdom, 33,415 in Italy, 28,802 in France and 27,127 in Spain.

With no vaccine nor specific treatment, being easily transmitted even by asymptomatic individuals, protection against COVID-19 used the same approaches as those employed a hundred years ago in the Spanish Flu pandemic of 1918. That is, social distance and cleanliness. The rising death number and the impotence in the absence of a treatment that could certainly lead to a cure has generated a great degree of stress, depression, and even panic worldwide.

The rapid spread of information, which could had been extremely beneficial, also brought along with it unclear, wrong, and/or exaggerated information about the pandemic. Several studies have shown that frequent exposure to social networks during the COVID-19 outbreak could be associated with the onset of mental health problems such as depression and anxiety, and in some circumstances even racism and political crises [Bastani and Bahrami, 2020; Depoux et al., 2020; Gao et al., 2020]. And Brazil was not immune to such effects. However, the use of social media has also made it possible to keep people in contact, provide information on ways of prevention, symptoms, public measures, and advances regarding research on the virus and the disease [O'Brien, Moore and McNicholas, 2020]. These media also acted beneficially by reporting number of cases, distribution, and improvement of the pandemic. Thus, in Brazil, in parallel with traditional media, social networks played an important role in the dissemination of information during this pandemic, but also produced some of the problems described in other countries [Lima, Medeiros Lopes and Brito, 2020].

In 2019 there were 3,484 billion social media active users spread around the world [Kemp, 2019a], with Facebook having 2,449 billion followers, YouTube 1,9 billion, Whatsapp 1,6 billion and Instagram 1 billion [Kemp, 2019a]. In Brazil, data from that same year showed the enormous reach of social media, since $81 \%$ of Brazilians over 13 years old used social media compared to $58 \%$ worldwide. The most accessed ones were YouTube (95\%), Facebook (90\%), Whatsapp (89\%), Instagram (71\%), Messenger (66\%) and Twitter (43\%) [Kemp, 2019b].

\section{Information sources used by the Deaf}

In a pandemic period, it is essential that information should be available through different means, to which the population should have access, and thus be enabled to put into practice what it is transmitted. This information can be conveyed by the media, or by official government channels in their different spheres. However, what has been observed is that the guidelines are not always available to everyone. The difficulty of information for people with disabilities has already been reported [Almeida, Schiaffino and Rumjanek, 2014; Hub Editorial, 2020; Rose, 2020; Shew, 2020]. 
The scientific journal Nature published this year, in the issue of March $17^{\text {th }}$, a Letter by Castro et al. titled "COVID-19: don't forget Deaf people" [Castro et al., 2020]. But were Deaf people considered in Brazil during this pandemic?

It is necessary to highlight the difficulty that Deaf people have in accessing information and, consequently, the risk they run of exposing themselves to dangers due to the absence of educational materials and News that contemplate their linguistic specificity in the use of Brazilian Sign Language (Libras). In addition of not being able to hear, the level of literacy among the Deaf is much lower than that of hearing people.

Santos and Santos [2016] point to the difficulty that TV, considered the main means of mass communication today, presents in not meeting the communicative needs of Deaf people:

the situation of people suffering from hearing loss appears in the mass media. Taking into account that television is the most used means of communication today and that $73 \%$ of people watch TV every day, there are more than 10 million Deaf or hearing impaired people trying to watch open TV channels, which often offer neither closed captioning nor a Libras window [Santos and Santos, 2016, our translation].

It is possible, thus, to point out the difficulty that presents itself to the Deaf in Brazil in this type of vehicle. The lack of adequate communication through Libras imposes segregation on this group. Although we have some initiatives in Libras via TV open channels, the time allocated is still only a few minutes a day. If we compare the amount of information in Portuguese, it is possible to say that the TV time destined or with accessibility for the Deaf is very small, less than 10 min daily in the open channel TV Brasil [TV Brasil, 2020].

In Brazil, according to a Federal Decree from 2004 [Presidência da República do Brasil, 2004] and the Brazilian Inclusion Law of 2015 [Presidência da República do Brasil, 2015], Deaf and hearing-impaired people should be assisted via subtitling, mainly on TV programs and newsreel, or should have direct access in sign language. This second option is almost nonexistent today. Among the strategies pointed out by the legislation is closed captioning [Araújo, 2004].

Although this mechanism seems to be the most adequate and capable of producing accessibility to part of the group of hearing-impaired people, it is worth noting that there is still a huge lack in the implementation of this feature in the Brazilian open TV. Among the problems pointed out by Santos [2014], there is a delay in the information written in front of the images and in relation to the messages, in addition, there is the rapid digitization of the words and their consequent appearance on the screen with mistakes. Unfortunately, these technical flaws have not yet been corrected, mainly due to allegations of technical unfeasibility, resulting from the lack of investment to use this resource on TV [Santos, 2014]. The problem of the use of television captioning for the Deaf is also discussed in other countries [Burnham et al., 2008; Cambra, Silvestre and Leal, 2009].

It should be added that during official appearances by members of the government talking about the pandemic, we observed that there was always the presence of an interpreter in person, however, many TVs channels cut the interpreter out of frame. 
In addition to traditional media, Brazil has had since 2013 a broadcaster, TV INES, aimed at the Deaf community, with all its programs in sign language, voiceover and subtitles in Portuguese [TV INES, 2020]. TV INES is very diversified and has educational programs, general issues and News [TV INES.org, 2020]. The programs specifically designed to News broadcast are Boletim (Bulletin), Primeira Mão (First Hand), Saber Mais (Knowing More), Panorama Visual (Visual Overview). However, TV INES is not broadcast on open TV, but through the internet and mobile phone apps.

Organization of dissemination networks among the Deaf
It is important to seek a perception of how information transmission networks function for the Deaf, as well as the resources used by these individuals in order to remain aware of the news related to the pandemic. By understanding how dissemination networks work, the production in sign language and its transmission, it might be possible to have an overview of the forms of access to information of this community. The analysis of how this has been constituted on the internet, so that the Deaf community could follow the advances of the pandemic, may contribute with the reflections on accessibility and the most useful and adequate tools for transmitting recommendations to Deaf people. It discusses the strategy the Deaf have been adopting to obtain the knowledge and information produced in this pandemic period and its implications.

The Deaf community chooses public areas for meetings, interactions, and information to be transmitted, no longer through an official or government channel, but through the transmission of information by its own members. The Deaf community is understood here from the perspective of Strobel, who understands that this "is not only about Deaf individuals, there are also hearing subjects - Family members, interpreters, teachers, friends and others who participate and share the same common interests in a given location" [Strobel, 2008]. The interaction between these entities tries to minimize the great difficulty of accessing information in sign language. The meeting points are the squares, shopping malls, bars and others, that somehow bring together Deaf people from different places. Although the use of internet has greatly reduced the use of these spaces, they were still utilized for this purpose. However, with the worsening of the pandemic, these physical meeting spaces have no longer been conducive to meetings.

This does not mean that the Deaf community has not found other spaces for interaction. Hall [1997] understands that relationships change quickly, and information has become increasingly accessible. This change pointed out by Hall, is not linked to spaces, but it can be virtual. The need for displacement and decentralization of physical locations contributed to the migration to a meeting space, digital-virtual interaction, whose centralities are unrelated to the geographical environment, but allow remote meetings through apps and social media.

The internet has contributed greatly to this new communicative dimension of Deaf people. The use of social media in the Internet allows people to organize themselves both in accessing and disseminating information. Social networks that allow for the sharing of videos, information and texts have been gaining prominence in the current scenario. People who would not have, otherwise, the 
means to carry out physical interactions are able to exchange messages and participate in discussions with friends and other individuals on social networks.

During the pandemic period attention turned to the importance of videos and sharing channels such as YouTube, Facebook and Instagram, for the Deaf community. Due to their configurations, they allow messages to be visual, and consequently can be transmitted through sign language.

Although there are several social media under study, regarding the relationship of the Deaf person with social networks, Ramos [2014] discussed the strength of Facebook for the Deaf community in Brazil. In this social network many groups participate in political, tourism, education, and health discussions. In addition, Facebook is seen as a "social network that, in a globalized moment, reduces the distance between people and makes everyone equal in access, there are no barriers, lack of information, everything is there, everyone posts, everyone reads, there are no limits to expressiveness, especially for the Deaf" (2014). This study is in line with international studies that analyzed the use of Facebook by Deaf people [Kožuh and Debevc, 2019]. Furthermore, an international experience during the disaster resulting from an earthquake in Italy has demonstrated the importance of this media to provide information for the Deaf community [Rotondi et al., 2019].

When faced with the lack of access to information related to the pandemic, many hearing people who are part of the Deaf community and many Deaf people who do translation work started posting informative videos about COVID-19. Initially they were posted only in personal profiles, however, already in the first week of decrees and determinations of social distancing, a Facebook group was created and named Central Libras/Coronavirus [Central Libras/Coronavirus, 2020]. This is a collective administration composed of Deaf and hearing sign language interpreters from different regions of the country, and aims to share information about the new coronavirus, the pandemic and the main news taking place in the country during this period. This group had a fast adhesion of the Deaf community and in May 2020 it already had more than 8,000 members.

Deaf people, as discussed above, have a more limited access to information. Usually the information sources do not contemplate the fact that they communicate in sign language and might have a lower level of literacy. Furthermore, Libras did not have signs for the terms that were being used during the pandemic, and this, in certain occasions, made comprehension difficult.

In an attempt to understand how Brazilian Deaf were informed about COVID-19 during this period, this paper analyzed what was published about the pandemic in four different media used by the Deaf in the period between January $14^{\text {th }}$ and May $31^{\text {st }} 2020$.

Methods

Due to the use of social media by the Deaf community, this source of information was investigated in the present work.

Different media were analyzed: a Facebook page, YouTube, Instagram and TV INES. The total period covered was from January $14^{\text {th }}$, when the first reports of 
Corona Virus started appearing on TV INES, up to May $31^{\text {st }}$, when the collection of samples for the study was ended. However, as described in the text, the different programs in TV INES lasted for different periods. The Facebook page Central Libras/Coronavirus was only created on March $17^{\text {th }}$ and the study went up to May $31^{\text {st }}$. The videos in the YouTube and Instagram analyzed were posted on March 21 st and the analysis covered up to May $31^{\text {st }}$. All videos posted in these media, during this time interval, were analyzed. Every media was seen by at least two of the authors, except for TV INES, that was covered by only one investigator. The total amount of views of each medium was compiled in the first week of June 2020. The group comprised a Deaf investigator, sign language interpreters and biological scientists.

Searching for places on social media, in which the information was reliable, in which Fake News was excluded, and in the impossibility of following all the information exchanged on social networks among the Deaf community, we chose to start by verifying the scope of the information present on the Facebook Central Libras/Coronavirus, created this year on March $17^{\text {th }}$ [Central Libras/Coronavirus, 2020]. One of the objectives of the 29 administrators of this page was to exclude fake news, so that it would never be posted, and during our search we did not find any. The search was conducted by us between March $17^{\text {th }}$ and May $31^{\text {st }}$, and all posts within this period were analyzed apart from, the very rare cases when a second copy of the same video was posted. The total of 387 videos was excluding duplicates.

To compare if there was a difference in access to videos posted on Instagram [Batista, 2020a] and YouTube [Batista, 2020b], we used the videos of the same person, a sign language interpreter and co-author of this work, and analyzed the period from March $21^{\text {st }}$ to May $31^{\text {st }}$.

The impact of journalistic programs produced by the web TV INES, was also analyzed. These programs are divided into different groups, each group is composed by a team with Deaf and hearing professionals, from different backgrounds and with different methodology for choosing the topics covered that will be presented in each program. Primeira Mão (First Hand), Saber mais (Knowing More), Plantão Coronavirus (Coronavirus Breaking News), Panorama Visual (Visual Overview), Boletim (Bulletin). They were analyzed at different times and this is explained in the Results section. The TV INES portal does not provide any statistical data regarding the number of accesses; therefore, we analyzed the TV INES page on Facebook [TV INES, 2020].

In the period from March $17^{\text {th }}$ to May $31^{\text {st }}$ a total of 387 videos were posted in the Facebook Central Libras/Coronavirus. These videos were comprised of the most diverse topics including precautions to prevent transmission, means of identifying symptoms of COVID-19, possible treatments, vaccine development, decrees suggesting social isolation, number of contaminated people and deaths, as well as news from daily newspapers. Of the total number of posts, those with the highest number of views (over 100 views) were analyzed. The sample was comprised of 95 posts. 
During the period under study the theme of the messages modified over time. The number of posts also decreased. During March, the first month, there were 208 posts and those related to the precautions to be taken predominated: hygiene, hand washing, cleaning the food, time that the virus lasted in various materials, symptoms of the disease, explanation of contagion, isolation, data on contamination and number of deaths in other countries and in Brazil.

In April, with 116 posts, social isolation is still discussed, the need for masks by the population appears more frequently, as well as the comparison between the lethality of COVID-19 and H1N1, epidemiological bulletins with number of cases and deaths in different parts of Brazil and lack of intensive care units (ICU) in public hospitals.

In May, the last analyzed period, the total number of posts dropped to 63. The almost daily announcement of the increase in the number of infected or killed as a result of COVID-19 in Brazil also aroused much less interest with 22 posts with a median of 12 views. During the same period, two interviews with a scientist talking about the development of the American and English vaccines, a post on bilingual hospital care and a video with a deaf pharmacist, presented more than 100 views, each indicating that the concern now turned more to the disease itself.

The themes of the most viewed videos during the total period (March $17^{\text {th }}$ to May $31^{\text {st }}$ ) were analyzed monthly. In March, a video on the cases of COVID-19 in Brazil received great attention because it was the beginning of the epidemic in this country, but at the same time what was happening in Europe was still news and another video with posted pictures of hospital nurses in Italy was the second most viewed of the period. In April, the two most viewed videos were: a video about the death by COVID-19 of an interpreter, and a video reinforcing the need to stay at home. In May the video of an interview explaining the English vaccine, and the video of the pharmacist were the most viewed ones.

When doing this survey, we found that in some situations the same video on YouTube had a higher number of views. To verify if another social media could also reach the Deaf public, videos posted on an Instagram channel were also analyzed. Videos from both media posted during the period from March $21^{\text {st }}$ to May $31^{\text {st }}$ were examined.

On Instagram, with 42 videos analyzed, views ranged from 25 to 267 views per video with a median of 48 views. The most viewed video was one that said that boldo tea for the cure of COVID-19 was Fake (267 views). The subject of Fake News proved to be of interest to the Community and a video against this practice received the third largest view (195 views). The second most viewed video was one that showed that Rio, in 24hours, surpassed the data of São Paulo, until then the epicenter of the pandemic in Brazil (206 views). This is consistent with the fact that another one with many views was that in which the gradual reopening of the city was announced (152 views). Finally, the fifth most viewed video discussed self-medication and Ibuprofen (135 views).

On YouTube, 47 videos were analyzed in the same period and the median of views was slightly lower, 40 views, varying in a very wide range from 3 to 918 views. Once again, the subject Fake News gained attention and the most viewed video 
was one that showed that it was fake the news of looting supermarkets (918 views). The second most viewed video was sex and corona virus (560 views), followed by the same one that had featured many views on Instagram stating that the cure through drinking boldo tea was fake (523 views). The fourth video explained the problem of men with beards and the corona virus (396 views), and the fifth most viewed video was a statement by the governor of Rio de Janeiro (354 views).

\section{TV INES and information about the pandemic}

As previously mentioned, the existence of an accessible web TV for both the Deaf and hearing people, TV INES, could partially supply the lack of accessibility on open TV channels. During this period, TV INES covered the main news that were featured in the mainstream media through its journalistic programs. The following paragraphs will introduce the different programs, analyze the methodology of each nucleus, as well as the purpose of each program produced.

Primeira Mão (First Hand). The Primeira Mão group has as its flagship the Jornal Primeira Mão (First Hand News), a news program that is available on the TV INES portal and on social networks, such as Facebook. Before the pandemic, the team met on Mondays at the company's headquarters, and each team member was responsible for bringing their news suggestions based on what they searched in the mainstream media. The Deaf presenters, as representatives of the Deaf community, were the first to give their suggestions. After the presentation of the suggestions of the whole team, the chosen themes were divided among the journalists who wrote the stories that would be recorded the next day. On the day of the recording of the program, a Libras sign language interpreter studied the Portuguese text with the Deaf person and passed it on to glosa, a translation resource that describes the structure of the sign language using Portuguese words, and would be placed on the teleprompter to be signaled by the Deaf presenters.

Each program of the Jornal Primeira Mão lasts an average of three to four minutes and is broadcast from Monday to Friday. It is also available on VOD (video on demand) and social networks, and it can be accessed anytime. The videos are all presented by Deaf people in Libras, have voiceover and subtitles in Portuguese, reaching a diverse audience that include deaf sign language users, oralized deaf people and hearing language learners.

During the period from January $14^{\text {th }}$ to March $23^{\text {rd }} 2020$ a total of 10 programs on the Coronavirus theme were addressed with 12,079 views, 30 comments and 785 reactions, according to a survey on the TV INES page on Facebook.

From March $23^{\text {rd }}$, the city of Rio de Janeiro began to adopt measures to contain the spread of the virus and the work began to be carried out in the form of home office. Without the structure of the company to do the editing, subtitling and voiceover, Jornal Primeira Mão was discontinued during this period of social isolation.

Saber Mais (Knowing More). The same First Hand group is also responsible for the Saber Mais and Plantão (Breaking News) programs. Saber Mais came up with the need to deepen a subject that was brought up in a Jornal Primeira Mão, but unknown 
to the majority of the Deaf Community. In Saber Mais this subject is explained more deeply so that the Deaf take ownership of the concept and thus, when the topic appears at another time in the news, they already have prior knowledge.

During this period of the emergence of the SARS-Cov2 virus and the disease COVID-19, two programs were produced with the related theme, one explaining what a corona virus is, and the other what is the meaning of quarantine. The need to make this meaning explicit arose because there was a doubt whether quarantine would mean 40 days in isolation.

The programs were made available on digital platforms on February $1^{\text {st }}$ and March $14^{\text {th }}$ and had a total of 20,200 views, 34 comments and 741 reactions.

Plantão Coronavirus (Coronavirus Breaking News). Plantão (Breaking News) presents important issues that come up when information and the news in Jornal Primeira Mão have an urgent need to reach the public. It is a program that does not need a large postproduction, as it has no subtitles or voiceover. At the beginning of the pandemic, it was posted under the name Coronavirus, later modified to Plantão Coronavirus. After the stoppage of TV activities and the need of the work to be carried out under the form of home office, the team responsible for the program did not have the studio resources, editing, subtitling, and voiceover, and as of March $23^{\text {rd }}$ it started to produce only Plantão Coronavirus.

During the period from March $6^{\text {th }}$ to May $20^{\text {th }}, 75$ programs were produced with a total of 136, 976 views, 286 comments and 7613 reactions.

Panorama Visual (Visual Overview). The Panorama Visual team is responsible for several productions. Presenting a diversified content such as tourism tips, gastronomy, fashion, Panorama Visual also presents topics relevant to society, such as the pandemic. During this period, the program interviewed several professionals who addressed important issues in this pandemic era.

Between March 4th and May 30 th there were 14 programs totaling 7,883 views, 38 comments and 602 reactions.

Boletim (Bulletin). Finally, the Boletim center holds the responsibility of bringing important information into the lives of Deaf citizens. It is usually a topic that has not been addressed by other News programs or that needs an update. The first Boletim that addressed the issue of Coronavirus was broadcasted when the virus had not yet crossed the limits of China. This program updated information that had been presented in other programs and commented what the authorities of that country were doing to contain the progress of the disease. Boletim programs with several themes were produced during the period since that first program that dealt with the coronavirus.

There was a total of 15 programs that addressed issues related to the pandemic, between January $24^{\text {th }}$ to April $12^{\text {th }}$, with 13,650 views, 26 comments and 735 reactions. 
In view of the period of social isolation, information about various services and their functioning is essential. However, not everyone has access to safe and clear information with official channels in sign language.

In Brazil, a time of intense movement is Carnival, which this year took place between February $21^{\text {st }}$ and February $26^{\text {th }}$, concurrent to the first case of COVID-19 detected in the country. During this time many people entered and left the country in addition to intense domestic tourism. The first case in Brazil was detected on February $26^{\text {th }}$ and the first death less than a month later. Despite this, tourism continued, and the first measures only started to take place on March $19^{\text {th }}$, when the Federal Government determined, due to the coronavirus pandemic, the closure of borders with the countries of South America. The determination applied to highways, but not to airports. And beside that, it would not affect Brazilians who were in these neighboring countries. Without having access to concrete information in Libras, the Deaf person found himself unable to continue planned trips. With the intention of minimizing the financial impacts as a result of cancellations of interstate flights and buses, the Ministry of Tourism, through the 'Do not cancel! Reschedule!', advised on postponing trips and cultural events, giving guidelines for maintaining the sector's business. It also drew up a provisional measure to regulate cancellations and reschedules in the area. Such information did not have accessibility in Libras. However, despite the lack of information, we did not find programs or videos in Libras warning Deaf people about what to do in these circumstances.

On the other hand, in the cultural tourism segment, we are faced with information about the functioning of museums, available on YouTube in Portuguese and in Libras. The Museu do Amanhã (Museum of Tomorrow), for example, published a video in sign language, where it contains information on closing the museum (part 1) and guidelines for individual protection regarding hygiene and care to avoid contagion (part 2). Also, the TV INES Primeira Mão program offered virtual visits to several museums around the world, informing their electronic addresses. We notice that such initiatives are still few in the face of all the demands of the Brazilian Deaf Community.

Many other topics, which are quite relevant, were less addressed to the Deaf citizen. With the need for social isolation due to the current pandemic, and similar to what has been observed in other countries, domestic violence has increased in this period. Thus, we were faced with the concern which is the attention to women and children who are victims of this type of violence. The TV INES program Plantão Coronavirus, displayed, on May $22^{\text {nd }}$, a video in Libras with information about the launch of an app by the Ministry of Women, Family and Human Rights, with the name of Human Rights of Brazil that contains the step by step information on how to report domestic violence. The video was published on May $22^{\text {nd }}$ and until June $5^{\text {th }}$ had 328 views. However, in the media that were analyzed in this study, this was the only video found on the subject.

Little was found on where Deaf communities could obtain information and guidance for children and their doubts about the pandemic period. However, TV INES, through two programs, made videos available to children and their parents. 
In the video "Corona, the virus" information about COVID-19 is presented in Libras, showing ways of contagion and how to avoid it. This video was played on various social media. Another video, telling a children's story in Libras and showing the illustrations, "The Protective Shield against King Corona virus" can be found on Facebook Central Libras/Coronavirus. At this same address, three other videos could also be found, a children's story in Libras about an earthworm, one with a small Italian boy talking about the pandemic with interpretation in Libras and another with a Brazilian girl.

The program Fica a Dica (Tips), also on TV INES, provided guidance for parents to deal with children and the proper care that should be taken, including the electronic address for online care that aims to answer questions about the corona virus for the Deaf community. This video was also played by other social media.

\section{Scientific content of information}

We live in an age in which, despite all the accumulated scientific knowledge, we find ourselves surrounded by anti-scientific views of the world [Hotez, 2020]. In Brazil this is not different and, in certain groups, we even returned to the acceptance of the Flat Earth Theory [De Albuquerque and Quinan, 2019]. This occurs despite the fact that, in 2013, the majority of the population displayed a positive attitude towards science [Castelfranchi et al., 2013]. Additionally, during the pandemic, the news in general stressed the importance that decisions should be made based on science [Fraser, 2020]. In this dichotomous scenario, it was observed that aspects related to the scientific knowledge of the virus were rarely addressed, even less for the Deaf. In general, basic science education for the Deaf community is deficient in Brazil. This, in addition to the vast amount of circulating misinformation, hindered the conscious decision making in this pandemic period.

The most specific and in-depth information about the infection and the disease did not circulate effectively among the Deaf. As already mentioned, the majority of videos translated into Libras, are made voluntarily by interpreters and this means that deeper scientific themes are only translated when there is an interest of the person translating, which is often correlated with the technical capacity of the interpreter and his/her understanding of the subject.

We believe some concepts were clear, such as contagion, for which a number of videos and animations focused. Others, for example, the susceptibility of people with blood type A, or how the SARS-Cov2 virus reproduces, proved to be too complex and aroused no interest. But it is important to report that the basic scientific knowledge of this group is weak. We also detected the explanation of the tests for COVID-19. Interviews, carried out with simultaneous interpretation in Libras, with a microbiologist well known as a Science communicator for the hearing audience, were also problematic due to the speed with which information was transmitted and the small size of the sign language window. On the other hand, there was an interest in understanding about possible vacines, despite the fact that these were also videos of scientists speaking Portuguese with interpretation in Libras.

Visual understanding for the Deaf is essential. In this context, the videos need to be visually adapted bringing clearly aspects of the virus, such as what happens when 
it infects the cell in a detailed way. Especially if one considers the absence of technical/scientific signs in the area.

\section{Clarity of information}

According to data analysis, since the appearance of the first newscasts related to COVID-19, there have been numerous attempts disseminated on social media on the transmission of this information in Libras. Not only was the subject itself a great novelty and unknown by a large part of society, but it also required considerable linguistic efforts so that such information could be translated in Libras in a coherent and effective manner.

The first videos with information about the new corona virus took place in January and the development of a specific sign for corona virus dates from that time. However, the SARS-Cov2 sign itself is a source of discussion as described by Amorim et al. [2020]. These authors, studying various media, found up to three variants of the sign and discussed which one had better acceptance among the Deaf. Along with the virus itself, the appearance of several terms that had no translation in Libras also had to be explained. An explanation of the use of some of these terms can be found on April $11^{\text {th }}$ in a video on Facebook Central Libras/Coronavirus. As previously verified, the same video on Facebook had 56 views and on YouTube 349 views. In parallel, several glossaries with new signs for these terms have emerged, such as the one created by Prof. Gildete da S. Amorim, at Universidade Federal Fluminense [Amorim, 2020], but without widespread adoption. As a result, the newscasts started to use more than one sign for the same term.

Basically, terms such as: COVID-19, VIRUS, CORONA VIRUS, PANDEMIC, EPIDEMIC, QUARANTINE, SOCIAL ISOLATION, INFECTION, CONTAGION, TRANSMISSION, SUSPECTED CASES AND CONFIRMED CASES were the most used in the making of these news, drawing attention to their concepts, meanings and order of words in Libras syntactic operations.

As discussed by de Quadros [2003] it is necessary to know the proper order of words to communicate in sign languages so as to structure the sentence correctly. As mentioned by de Quadros, the authors Felipe [1989] and Ferreira-Brito [1995] present in their work the flexibility of the word order in Libras and point out different possibilities for the ordering of the words in the sentence, although they culminate in the understanding of the existence of a basic order SUBJECT — VERB - OBJECT (SVO).

Therefore, we can start the investigation of the clarity of news and texts presented in this context in Libras, observing the basic structural order of the sentences.

A second structural form that can be analyzed regarding the sentences produced in Libras is what it is called topicalization, when the resulting sentence order is OBJECT — SUBJECT - VERB (OSV).

Following the analysis of the materials published in Libras on COVID-19, it was possible to observe the use of different possibilities regarding the ordering of words 
in sentences. However, in many cases, the choice for a certain model seemed to significantly compromise the understanding of what was being announced. Let us take as an example, the repeated use of the term PANDEMIC which, not having a sign, when translated into Libras, ends up assuming a different understanding from the one intended in the source language.

For example, in the original sentence:

“... The confinement to contain the pandemic of the new coronavirus has triggered calls for help by battered women ..."

Pandemic — Translation offered in sign language - Coronavirus + spread

Confinement — Translation offered in sign language — Need-stay-home

The signs used for the conceptualization of PANDEMIC and CONFINEMENT compromised the general understanding of the information when associated with the choice in the organization of the sentence in Libras, obscuring the real reason for staying at home or the incidence of domestic aggressions.

According to de Quadros and Karnopp [2004] among other groups, there are types of verbs in Libras called manual verbs (classifier verbs) that are those that use classifiers and incorporate action. Examples of this class of verbs are Put-Cake-in the-Oven, Sit-on the-Wall. It is possible to observe below, an example of the inappropriate use of a possible classifier verb for the context of contamination with the Coronavirus.

Coronavirus - Translation offered in sign language- Bite (in hand) + spread

Contract - Translation offered in sign language - Catch

Disseminate — Translation offered in sign language — Spread

Misunderstanding of the concept of CONTAMINATION using inattentive use of the classifier verb in Libras (Bite-in hand) making the lexical choices for the construction of sentences in sign language have compromised the real information contained in the source language.

In other instances, the wrong understanding of the word in Portuguese by the signer (emitter of the news), generated a sign formation in Libras and, consequently, a contextualization totally disconnected from the one proposed by the source language (Portuguese).

In Portuguese, the word for Contract (in the sense of contracting a disease), for example, is Contrair. The signer divided the word as Contra (against)+Ir (to go), so that the final idea instead of getting the disease was going against the disease, which would be totally opposite to the original meaning.

In an attempt to understand the term CONTRAIR, the sign maker chose to fragment the word, bringing to Libras the combination of two Portuguese words 
equivalents: CONTRA (against) + IR (to go). Therefore, as a result we have the distortion of that announced by the source language. Instead of the final idea being contracting the disease, it became going against the disease.

In another example:

“...patients with the Coronavirus that has killed more than 400 people. The virus influences the financial Market and China's stock Market fell more than $8 \%$ in one day. $(\ldots)^{\prime \prime}$

In this particular piece of news, they go on to explain the number of suspected cases and confirmed cases, as well as the importance of quarantine.

Confirmed cases - Translation offered in sign language - Corona+certain

Suspected cases - Translation offered in sign language - Corona+suspect

Quarantine - Translation offered in sign language -

Group+separate+contact+nothing

The lack of clarity regarding the choices in the order of words to explain the terms above, presents ambiguity as to WHO IS SUSPICIOUS and, finally, compromises the understanding of $\mathrm{WHO}$ or WHY quarantine is practiced.

\section{Conclusions}

There are studies in Brazil describing that Deaf individuals when pursuing information use social networks or gather information from friends [Barbosa et al., 2011; Almeida, Schiaffino and Rumjanek, 2014; Ramos, 2014]. Similarly, TV INES, a web TV created especially for the Deaf, is known to represent an important source of information for this community despite the absence of data on its total audience. During the COVID-19 pandemic, the absence of public authorities to make information available to the Deaf community was notorious. In this way, the information channels used by the Deaf remained the same as before.

But difficulties arose. As a result of social isolation, TV INES was unable to maintain its programming. The Plantão Coronavirus program was kept without subtitles, only serving the Deaf fluent in Libras. Even so, the reach of TV INES, compared to the other social media of this study, was very large. However, regarding TV and other means of information, an additional problem arose, the information resulting from the pandemic was new for everyone, including hearing individuals, and had many unknown terms in the Portuguese language and nonexistent in Libras.

The analysis of the information offered by the sources under study demonstrated the importance of videos of public utility, those that were intended to protect the individual against infection, including day-to-day care. However, videos intended to be of scientific dissemination, with information about the virus, the disease, medicines, etc. were proportionally few.

Deaf individuals should represent a priority group in receiving information during a health crisis such as the pandemic COVID-19. The knowledge of how the 
dissemination network of this community works, and the difficulties encountered by this linguistic minority in relation to obtaining information, will be useful tools to provide means to yield scientific information to the Deaf.

Acknowledgments

\section{References}

The authors would like to thank Dr. Lucia de La Rocque for the helpful comments and some editing of this paper. We would also like to acknowledge the support from Conselho Nacional de Desenvolvimento Científico e Tecnológico (CNPq), Fundação Carlos Chagas de Apoio à Pesquisa do Rio de Janeiro (FAPERJ).

Almeida, R. C. N., Schiaffino, R. S. and Rumjanek, V. M. (2014). 'Access and comprehension of information by profound deaf youngsters in Brazil'. Journal of Media and Communication Studies 6 (11), pp. 174-178. https://doi.org/10.5897/jmcs2014.0411.

Amorim, G. (2020). Glossário de libras do coronavirus COVID-19. [YouTube video]. URL: https: //www . youtube. com/watch?v=-snZOP7x_0A (visited on May 2020).

Amorim, G., Ramos, A. S. L., de Castro Junior, G., de Souza Afonso, L. and Castro, H. C. (2020). 'Coronavirus, deafness and the use of different signs of the area in health during a period of pandemic time: is that the best option to do?' Creative Education 11 (04), pp. 573-580. https://doi.org/10.4236/ce.2020.114042.

Araújo, V. L. S. (2004). 'Closed subtitling in Brazil'. In: Topics in audiovisual translation. Ed. by P. Orero. Amsterdam, The Netherlands and Philadelphia, PA, U.S.A.: John Benjamins Publishing Company, pp. 199-212. https://doi.org/10.1075/btl.56.20san.

Barbosa, G. A. R., Silva, I. S., Gonçalves, G., Prates, R. O., Benevenuto, F. and Almeida, V. (2011). 'Characterizing interactions among members of deaf communities in Orkut'. In: Human-Computer Interaction - INTERACT 2011. Ed. by P. Campos, N. Graham, J. Jorge, N. Nunes, P. Palanque and M. Winckler. Berlin and Heidelberg, Germany: Springer, pp. 280-287. https://doi.org/10.1007/978-3-642-23765-2_20.

Bastani, P. and Bahrami, M. A. (2020). 'COVID-19 related misinformation on social media: a qualitative study from Iran'. Journal of Medical Internet Research. https://doi.org/10.2196/18932.

Batista, T. (2020a). Tiago Batista Instagram page.

URL: https://www . instagram.com/tricolor_tiago?r=nametagw (visited on 5th June 2020).

- (2020b). Tiago Batista YouTube channel. URL: https://www . youtube.com/channel/UCEWojBE_p5zCZeEY1nFGLSQ (visited on 5th June 2020).

Burnham, D., Leigh, G., Noble, W., Jones, C., Tyler, M., Grebennikov, L. and Varley, A. (2008). 'Parameters in television captioning for deaf and hard-of-hearing adults: effects of caption rate versus text reduction on comprehension'. Journal of Deaf Studies and Deaf Education 13 (3), pp. 391-404. https://doi.org/10.1093/deafed/enn003.

Cambra, C., Silvestre, N. and Leal, A. (2009). 'Comprehension of television messages by deaf students at various stages of education'. American Annals of the Deaf 153 (5), pp. 425-434. https://doi .org/10.1353/aad.0.0065. 
Castelfranchi, Y., Vilela, E. M., de Lima, L. B., de Castro Moreira, I. and Massarani, L. (2013). 'Brazilian opinions about science and technology: the paradox of the relation between information and attitudes'. História, Ciências, Saúde-Manguinhos 20, pp. 1163-1183. https://doi.org/10.1590/S0104-59702013000400005.

Castro, H. C., Ramos, A. S. L., Amorim, G. and Ratcliffe, N. A. (2020). ‘COVID-19: don't forget deaf people'. Nature 579 (7799), pp. 343-343. https://doi.org/10.1038/d41586-020-00782-2.

Central Libras/Coronavirus (2020). Central Libras/Coronavirus. Facebook group. URL: https://www . facebook. com/groups/918648301921031 (visited on 5th June 2020).

Croda, J., de Oliveira, W. K., Frutuoso, R. L., Mandetta, L. H., Baia-da-Silva, D. C., Brito-Sousa, J. D., Monteiro, W. M. and Lacerda, M. V. G. (2020). 'COVID-19 in Brazil: advantages of a socialized unified health system and preparation to contain cases'. Revista da Sociedade Brasileira de Medicina Tropical 53. https://doi.org/10.1590/0037-8682-0167-2020.

Cucinotta, D. and Vanelli, M. (2020). 'WHO declares COVID-19 a pandemic'. Acta Bio Medica Atenei Parmensis 911, pp. 157-160. https://doi.org/10.23750/abm.v91i1.9397.

De Albuquerque, A. and Quinan, R. (2019). ‘Crise epistemológica e teorias da conspiração: o discurso anti-ciência do canal "Professor Terra Plana"'. [Epistemological crisis and conspiracy theories: the anti-science speech of "Professor Terra Plana" channel]. Revista Mídia e Cotidiano 13 (3), p. 83. https://doi.org/10.22409/rmc.v13i3.38088.

de Quadros, R. M. (2003). ‘Phrase structure of Brazilian sign language'. In: Crosslinguistic perspectives in sign language research. Selected papers from TISLR 2000. Hamburg, Germany: Signum Press, pp. 141-162.

URL: https://www.researchgate.net/profile/Ronice_Quadros/publication /228459159_Phrase_Structure_of_Brazilian_Sign_Language/links/5487fe0 40cf289302e2ee700.pdf.

de Quadros, R. M. and Karnopp, L. (2004). Língua de sinais brasileira: estudos linguísticos. Porto Alegre, Brazil: Artmed.

Depoux, A., Martin, S., Karafillakis, E., Preet, R., Wilder-Smith, A. and Larson, H. (2020). 'The pandemic of social media panic travels faster than the COVID-19 outbreak'. Journal of Travel Medicine 27 (3). https://doi.org/10.1093/jtm/taaa031.

Felipe, T. A. (1989). 'A estrutura frasal na LSCB'. In: Anais do IV encontro nacional da ANPOLL. Recife, Brazil.

Ferreira-Brito, L. (1995). Por uma gramática das línguas de sinais. Rio de Janeiro, Brazil: Tempo Brasileiro.

Fraser, B. (20th May 2020). "Medications should be prescribed by doctors, not the president': leading Brazilian scientist discusses the pandemic'. Nature. https://doi.org/10.1038/d41586-020-01506-2.

Gao, J., Zheng, P., Jia, Y., Chen, H., Mao, Y., Chen, S., Wang, Y., Fu, H. and Dai, J. (2020). 'Mental health problems and social media exposure during COVID-19 outbreak'. PLOS ONE 15 (4), e0231924. https://doi.org/10.1371/journal.pone.0231924.

Gralinski, L. E. and Menachery, V. D. (2020). 'Return of the coronavirus: 2019-nCoV'. Viruses 12 (2), p. 135. https : //doi.org/10.3390/v12020135. 
Hall, S. (1997). 'The centrality of culture: notes on the cultural revolutions of our time'. In: Media and cultural regulation. Ed. by K. Thompson. London, U.K.: Sage, pp. 208-238.

Hotez, P. J. (2020). 'Combating antiscience: are we preparing for the 2020s?' PLOS Biology 18 (3), e3000683. https://doi .org/10.1371/journal . pbio. 3000683.

Hub Editorial (23rd April 2020). ‘COVID-19 poses unique challenges for people with disabilities'. HUB, Johns Hopkins Magazine. URL: https://hub. jhu . edu/202 0/04/23/how-covid-19-affects-people-with-disabilities/ (visited on May 2020).

Kemp, S. (30th January 2019a). Digital 2019: global internet use accelerates. URL: https://wearesocial.com/blog/2019/01/digital-2019-global-intern et-use-accelerates (visited on 10th May 2020).

- (31st January 2019b). Digital in 2019: Brazil. URL: https://datareportal .com/reports/digital-2019-brazil (visited on 10th May 2020).

Kožuh, I. and Debevc, M. (2019). 'The utilisation of social media among users with hearing loss: an analysis of Facebook communities'. Universal Access in the Information Society 19 (3), pp. 541-555. https://doi.org/10.1007/s10209-019-00658-x.

Lima, D. L., Medeiros Lopes, M. A. A. A. de and Brito, A. M. (2020). 'Social media: friend or foe in the COVID-19 pandemic?' Clinics 75, e1953. https://doi.org/10.6061/clinics/2020/e1953.

Lu, H., Stratton, C. W. and Tang, Y.-W. (2020). 'Outbreak of pneumonia of unknown etiology in Wuhan, China: the mystery and the miracle'. Journal of Medical Virology 92 (4), pp. 401-402. https://doi .org/10.1002/jmv . 25678.

O'Brien, M., Moore, K. and McNicholas, F. (2020). 'Social media spread during COVID-19: the pros and cons of likes and shares'. Irish Medical Journal 113 (4), p. 52. URL: http://imj.ie/social-media-spread-during-covid-19-the-pros - and-cons-of-likes-and-shares/.

Presidência da República do Brasil (2004). Decree number 5.296 from December 2, 2004 - DOU 03/12/2004. URL: http://www.planalto.gov.br/ccivil_03/_ato2 004-2006/2004/decreto/d5296.htm (visited on 5th May 2020).

- (2015). Law 13.146 from July 6, 2015. Statute of persons with disabilities - Brazilian Inclusion Law. URL: http://www.planalto.gov.br/ccivil_03/_ato2015-2018 /2015/Lei/L13146.htm (visited on 5th May 2020).

Ramos, F. M. (2014). 'A comunidade surda e o Facebook'. Revista Ampliar 1 (1). URL: https://gravatai.ulbra.tche.br/jornal/index.php/revistaampliar /article/view/31 (visited on 5th May 2020).

Rose, B. (28th April 2020). 'Coronavirus: lack of sign language interpreters leads to legal case against government'. BBC News.

URL: https://www. bbc.com/news/disability-52323854 (visited on 15th May 2020).

Rotondi, L., Zuddas, M., Marsella, P. and Rosati, P. (2019). 'A Facebook page created soon after the Amatrice earthquake for deaf adults and children, families and caregivers provides an easy communication tool and social satisfaction in maxi-emergencies'. Prehospital and Disaster Medicine 34 (02), pp. 137-141. https://doi.org/10.1017/s1049023x19000086.

Santos, R. C. M. A. and Santos, F. C. (2016). 'Televisão e acessibilidade: o uso de recursos de inclusão para o surdo no telejornal brasileiro'. Revista Anagrama: Revista Científica Interdisciplinar da Graduação 10 (2). URL: http://www.revistas. usp. br/anagrama/article/view/118033. 
Santos, T. B. (2014). 'A inclusão/exclusão dos surdos por meio da legendagem no cinema nacional'. Master Degree Dissertation. Rio de Janeiro, Brazil: PPGEDu and UNIRIO. URL: http://hdl . handle.net/unirio/12304.

Shew, A. (2020). 'Let COVID-19 expand awareness of disability tech'. Nature 581 (7806), pp. 9-9. https://doi .org/10.1038/d41586-020-01312-w.

Strobel, K. (2008). As imagens do outro sobre a cultura surda. ISBN-10:853280778X. Florianópolis, Brazil: UFSC.

TV Brasil (2020). TV Brasil webpage. URL: https: //tvbrasil . ebc .com. br/visual (visited on June 2020).

TV INES (2020). TV INES. Facebook group. URL: https://www. facebook. com/tvines . oficial/ (visited on 3rd June 2020).

TV INES.org (2020). TV INES.org webpage. URL: http: //tvines .org.br/ (visited on 5th May 2020).

Werneck, G. L. and Carvalho, M. S. (2020). 'A pandemia de COVID-19 no Brasil: crônica de uma crise sanitária anunciada'. Cadernos de Saúde Pública 36 (5), e00068820. https://doi .org/10.1590/0102-311x00068820.

Worldometer (2020). COVID-19 coronavirus pandemic webpage.

URL: https: //www . worldometers . info/coronavirus/ (visited on 8th June 2020).

Alexandre G. Silva. B.A. in Portuguese Language and Literature, Interpreter and Translator Brazilian Sign Language, Coordenadoria de Comunicação Social - COMSO, UNIRIO, Rio de Janeiro. Part of Projeto Surdos (Deaf Project) - UFRJ, Medical Biochemistry Institute Leopoldo de Meis, Universidade Federal do Rio de Janeiro, Rio de Janeiro, Brazil. E-mail: alexgsilva3@gmail.com.

Tiago Batista. M.A. in Education, Professor, Departamento de Didática, Centro de Ciências Sociais e Humanas - CCHD, UNIRIO, Rio de Janeiro. Part of Projeto Surdos (Deaf Project) - UFRJ, Medical Biochemistry Institute Leopoldo de Meis, Universidade Federal do Rio de Janeiro, Rio de Janeiro, Brazil.

E-mail: tiagointerprete@hotmail.com.

Felipe Giraud. B.A. in Pedagogy, Interpreter and Translator Brazilian Sign Language, Núcleo de Apoio As Pessoas com Necessidades Educacionais Especiais, Instituto Federal Fluminense - IFF Campus Macaé, Macaé. Part of Projeto Surdos (Deaf Project) - UFRJ, Medical Biochemistry Institute Leopoldo de Meis, Universidade Federal do Rio de Janeiro, Rio de Janeiro, Brazil.

E-mail: giraudfgm@hotmail.com.

Andrea Giraud. Interpreter and Translator Brazilian Sign Language, Núcleo de Acessibilidade Linguística, GIRAUD Traduções e Eventos, Rio das Ostras. Part of Projeto Surdos (Deaf Project) — UFRJ, Medical Biochemistry Institute Leopoldo de Meis, Universidade Federal do Rio de Janeiro, Rio de Janeiro, Brazil.

E-mail: andygiraud@hotmail.com.

Flavio Eduardo Pinto-Silva. Ph.D. in Biological Chemistry, Coordinator of the center ESPECIE-A, Instituto Nacional de Educação de Surdos, MEC, Rio de Janeiro. Part of Projeto Surdos (Deaf Project) — UFRJ, Medical Biochemistry Institute Leopoldo de Meis, Universidade Federal do Rio de Janeiro, Rio de Janeiro, Brazil. E-mail: flavioedu@ines.gov.br. 
Julia Barral. Ph.D. in Biological Chemistry, Research Coordinator, Instituto Brasil Social - IBS, Rio de Janeiro. Part of Projeto Surdos (Deaf Project) — UFRJ, Medical Biochemistry Institute Leopoldo de Meis, Universidade Federal do Rio de Janeiro, Rio de Janeiro, Brazil. E-mail: juliabarral79@gmail.com.

Juan Nascimento Guimarães. B.A. in Brazilian Sign Language, Research assistant, Projeto Surdos - UFRJ, Medical Biochemistry Institute Leopoldo de Meis, Universidade Federal do Rio de Janeiro, Rio de Janeiro, Brazil. Part of Projeto Surdos (Deaf Project) - UFRJ, Medical Biochemistry Institute Leopoldo de Meis, Universidade Federal do Rio de Janeiro, Rio de Janeiro, Brazil.

E-mail: j10.juuan@gmail.com.

Vivian M. Rumjanek. Ph.D. Immunology, Full Professor, Medical Biochemistry Institute Leopoldo de Meis, Universidade Federal do Rio de Janeiro, Rio de Janeiro, Brazil. Head of the Projeto Surdos-UFRJ Project. Part of Projeto Surdos (Deaf Project) - UFRJ, Medical Biochemistry Institute Leopoldo de Meis, Universidade Federal do Rio de Janeiro, Rio de Janeiro, Brazil.

E-mail: vivianrumjanek@yahoo.com.br.

\section{How to cite}

Silva, A. G., Batista, T., Giraud, F., Giraud, A., Pinto-Silva, F. E., Barral, J., Guimarães, J. N. and Rumjanek, V. M. (2020). 'Science communication for the Deaf in the pandemic period: absences and pursuit of information'. JCOM 19 (05), A05. https://doi.org/10.22323/2.19050205. 